ACTA THERIOLOGICA

Vol. 28, 1: 3-24, 1983

\title{
Reproduction, Maternal and Social Behaviour of the European Water Shrew under Laboratory Conditions
}

\author{
Iwona MICHALAK
}

Michalak I., 1982: Reproduction, maternal and social behaviour of the European water shrew under laboratory conditions. Acta theriol., 28, 1: 3-24 [With 7 Tables, 1 Fig. \& Plates I-II]

The European water shrew, Neomys fodiens (Pennant, 1771), was reared in captivity during 1978-1981. Data were obtained from 18 litters (113 young), including 8 litters born to females caught pregnant in the field and 10 litters born to females that mated in the laboratory. Data on the reproduction were collected. Copulation is described, and the duration of pregnancy (19-21 days) and lactation (38-40 days) is determined. Litter size varied from 3 to 8 (15), with an average of $5.76 \pm 1.45$, excluding one litter of 15 young. The females produced $1-2$ litters on the average, and only one female delivered 6 litters. Maternal behaviour is described. Females rearing young are very aggressive, they chase and attack males put into their cages, and even bite the hands of observers checking the nest. Close maternal-weaning bonds are maintained after the young leave the nest at $23-25$ days. At that time contact behaviour can be observed among family members. It can be manifested in sharing the nest, or in huddling together when disturbed, e.g., after putting them into a new cage without nestboxes. The female is able to recognize her offspring after 2.5 days of separation. The occurrence of social behaviour in the family of Soricidae is discussed. The siblings of Neomys fodiens, Sorex minutus, and Cryptotis parva have been classified as species in which social bonds are clear-cut for some time after weaning.

[Mammals Research Institute, Polish Academy of Sciences. 17-230 Białowieża, Poland]

\section{INTRODUCTION}

Early attempts at rearing shrews in captivity were made by Pearson (1944, 1950), Crowcroft (1951, 1957a, b), Kilham (1951), Dehnel (1952), Rudd (1953), Lorenz (1957), Schewntker (1957), and Rood (1958). Most of these authors were only able to keep animals in captivity for a few months. They made many behavioural observations, but the captive shrews did not breed. Only Pearson (1944) obtained litters from captive Blarina brevicauda (Say, 1823) and Dehnel (1952) described copulation in the common shrew, Sorex araneus Linnaeus, 1758, and rearing of the young by a female that had mated in the wild.

In subsequent years more and more papers announced the reproduction in captive Soricidae. Conaway (1958) obtained a few litters from captive Cryptotis parva (Say, 1823). The young were reared by their 
mothers until they became self-sufficient. Mock and Conaway (1976) obtained as many as 327 litters from Cryptotis parva. Suncus murinus Linnaeus, 1766 were successfully reared in captivity by Dryden (1968, $1969,1975)$. Vogel $(1970,1972)$ even obtained 5 litters from one female of Suncus etruscus Savi, 1832 as well as 4 litters from Crocidura russula Hermann, 1870. Fons (1972) described the postnatal development of C. russula. Hellwing (1973) obtained 10-15 litters of C. russula including 4-10 successive litters at regular intervals interspersed with infertile periods. He maintained breeding $C$. russula in monogamous pairs over the year. Hanzák (1965) and Vlasák (1972) studied the reproductive biology of Crocidura suaveolens (Pallas, 1811). Vlasák (1972) even obtained 6 litters from one female and 5 litters from each of two other females. Vogel $(1972,1973)$ attempted breeding captive Sorex araneus and Neomys fodiens (Pennant, 1771). Hutterer $(1976,1977)$ described the conditions of rearing and gave a detailed description of the postnatal development of Sorex minutus Linnaeus, 1766, based on three litters from females that had mated in the field.

The present paper describes conditions for rearing Neomys fodiens in captivity, some data on their reproduction and behaviour in particular, mother-offspring relations.

\section{MATERIAL}

The rearing of captive water shrews was begun in the summer of 1978. Initially the main objective was establishment of optimum maintenance conditions so that they could reproduce subsequently. In 1979 the stock markedly increased by addition of wild-caught shrews and attempts were made to bring the animals to breeding condition. Only in 1980 more litters were obtained however. The experiment was ended in June of 1981.

The material obtained consists of 18 litters, including 10 from females that mated in captivity and 8 from females that mated in the field (Table 1).

\section{REARING METHODS}

\subsection{Trapping Methods}

Water shrews were captured in metal cones $45 \mathrm{~cm}$ high, with moss and meat on the floor. The were immediately brought to the laboratory, put into cages and supplied with fresh food, water, and milk. Frequent checking of traps, basically every two hours, is of great importance, and the animals should be put into the proper breeding cages on the night of capture. Otherwise most shrews die after a short time of captivity.

Trapping was started in April and continued with short breaks until first ground frosts, i.e., approximately by the end of October. 


\subsection{Breeding Cages and Their Equipment}

Plastic cages $(38 \times 30 \times 16 \mathrm{~cm})$ were used. When it was needed, they were joined by means of a rubber tube. For this purpose the cages had holes on their sides, closed with metallic shutters when the cages were used singly (Plate I, Photo 1). They were covered from above with a wire mesh in a wooden frame. The cage floor was covered with a $2-4 \mathrm{~cm}$ of sand. Sometimes also peat and sawdust were added. Moss and dry leaves were scattered on the sand. Ceramic flower-pots with an entrance hole were used as nestboxes. They were lined with moss and crushed dry leaves. At the beginning the pots were placed on clay saucers but it was noticed that shrews did not like to use the entrance hole into the pot, preferring pots standing directly on sand. They burrowed into the sand under

Table 1

Number of $N$. fodiens litters born in captivity in different years.

\begin{tabular}{lccr}
\hline \multicolumn{4}{c}{ Number of litters (no. of young) : } \\
Year & $\begin{array}{c}\text { From females fertilized } \\
\text { in the wild }\end{array}$ & $\begin{array}{c}\text { From females fertilized } \\
\text { in captivity }\end{array}$ & Total \\
\hline 1979 & $2(12)$ & $1(3)$ & $3(15)$ \\
1980 & $4(34)$ & $7(39)$ & $11(73)$ \\
1981 & $2(14)$ & $2(11)$ & $4(25)$ \\
Total & $8(60)$ & $10(53)$ & $18(113)$ \\
\hline
\end{tabular}

the pot and tightly closed with moss the entrance hole. Saucers were placed under glass food bowls and the shrews burrowed under them, and had an additional shelter there.

\subsection{Food}

A standard shrew diet for shrews was established, having a mixture of meat as the main ingredient. This diet consisted of approximately $30 \%$ beef pluck (liver, spleen, lungs, kidneys, heart), approx. 10\%, fish (mostly sea fish), approx. $30 \%$ chickens or rabbit and guinea-pig carcases, approx. $10 \%$ boiled or fresh hen eggs, approx. $10 \%$ sprouted wheat grain, and was supplied as a ground, wellmixed pulp. It was noticed that shrews preferred milk to water, so only milk was provided. Meat and milk were served in small glass bowls. The diet of lactating females was supplemented with meal worms (Tenebrio molitor) larvae, put into the bowls containing a small amount of water to prevent larvae from escaping. Animals in very poor condition were additionally supplied with the liver, heart, lungs, and brain of laboratory mice. In summer live frogs were supplied and eaten by the shrews.

\subsection{Cage Cleaning}

Cages were thoroughly cleaned every two weeks; in the meantime only dirty sand was removed from places serving as latrines. Shortly before cleaning the animals were placed in new, earlier prepared cages. Moss, leaves and sand were removed, and the cages, pots, and clay saucers were washed with warm water, and dried. Undirtied moss and leaves were frequently transferred to new nests. 
Cages of pregnant females were usually cleaned two or three days before parturition. In these cases part of leaves and moss from their old cages was put into transfer cages, to minimize distressing the female. Two nestboxes, one in each of the two connected cages, were provided. Most often the old pot was left, and frequently its content was not exchanged, and another, new pot was added. After birth cages were not thoroughly cleaned until the young left the nest, at most moss and dry leaves were added or the latrines removed.

\subsection{Distribution of Shrews among Cages}

Wild-caught shrews were sexed, and classified by age as mature or immature. Immature shrews of the same or different sex were paired in double cages. Mature females were kept in single cages for a few days to see whether or not they were pregnant. If pregnancy was noticed, a second cage was joined, or the female was moved to new cages. If pregnancy was not indicated, the female was put into the cage of an adult male, or the paired animals were placed in new cages. As a rule, the male was not put into the cage already occupied by a female to prevent the dominance of the female over the male.

Families with the young leaving the nest were housed in 3,4 , or even 5 cages connected in a row, depending on the number of young. Such series of cages contained nestboxes corresponding to the total number of animals.

\section{RESULTS}

\subsection{Description of Copulation}

Many attempts were made to observe the copulation by direct observing paired animals for a few hours both during the day and at night. Unfortunately, only one attempt was successful. Female 107 was paired with male 114 at 13.00 . At first, she attacked the male. He responded by laying motionless on his back but subsequently continued pursuing her. A few minutes later the female changed her behaviour. She stopped attacking, started to follow the male, and initiated contacts with him. Both animals uttered soft squeaks, which apparently enabled the male to locate the female, which occasionaly hid. The mutual interest of the shrews grew and the animals stopped responding to the voices of the observers. After an hour of interacting, the male seized the female by the scruff, but she tored herself away from him. The male seized her again and this time she did not escape. A few characteristic copulatory movements were observed. Then the animals shifted position, so that, the female laid on her belly and the male on his back, their heads facing opposite directions. After a while, they turned themselves on one side (Fig. 1) and remained joined motionless in this position for about one minute. When touched with a hand to determine whether they were coupled, the shrews did not respond. Similarly, Hasler et al. (1977) observed that Suncus murinus after a typical ejaculatory 
behaviour turned themselves on their sides and remained in this position for a few seconds. Contact was broken by the male. The animals rested for a while, and finally went apart. The female licked her genital region and the shrews ignored each other. They were separated at 15.45 and rejoined at 16.45 . They were observed until 20.00 but the animals ignored each other except for squeaking and retreating in opposite directions after encounters. They were separated, and the female was isolated but no young were found after 20 days.

\subsection{Duration of Pregnancy}

To determine the maximum duration of pregnancy the date of introduction of a male and the date of parturition were noted (Table 2). In only one case (litter No. II of female 64 ) was it possible to determine precisely the duration of pregnancy ( 20 days) since this female had

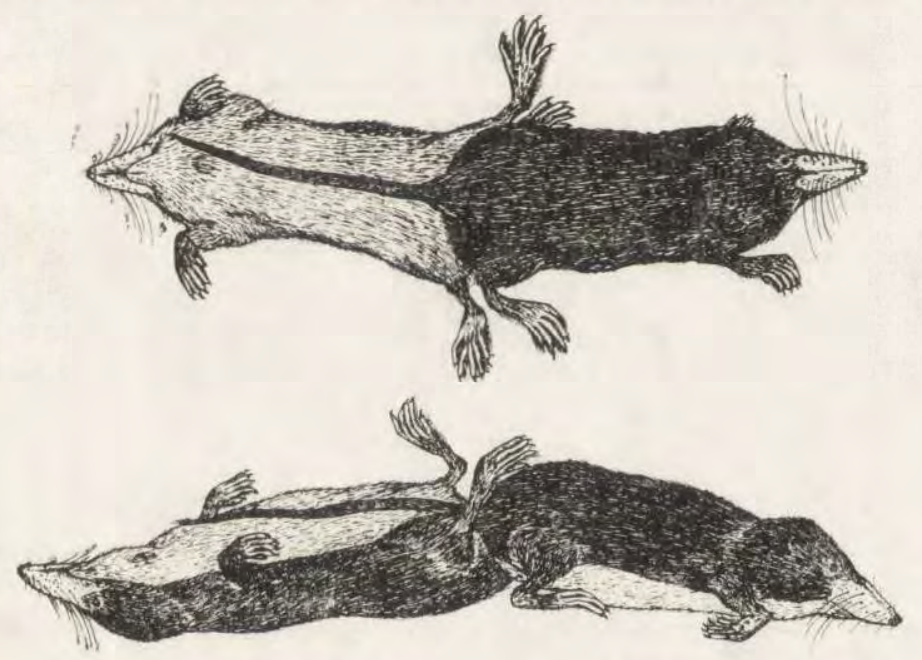

Fig. 1. Positions of water shrews after copulation (view from above).

a post-partum oestrus, and the male was removed immediately after copulation. In the other cases the day of mating was not exactly known because the male was with the female for more than one day. The minimal periods between pairing and parturition were 19 days ( 2 observations), 20 days (one observation), 21 days (2 observations) (Table 2). Other durations were in excess of 21 days. It can therefore be concluded, that pregnancy in the water shrew lasts for 19-21 days. These data are consistent with those of Vogel $(1972,1973)$, who gives a figure of 20 days.

There is some doubt about the duration of pregnancy in female 18, 


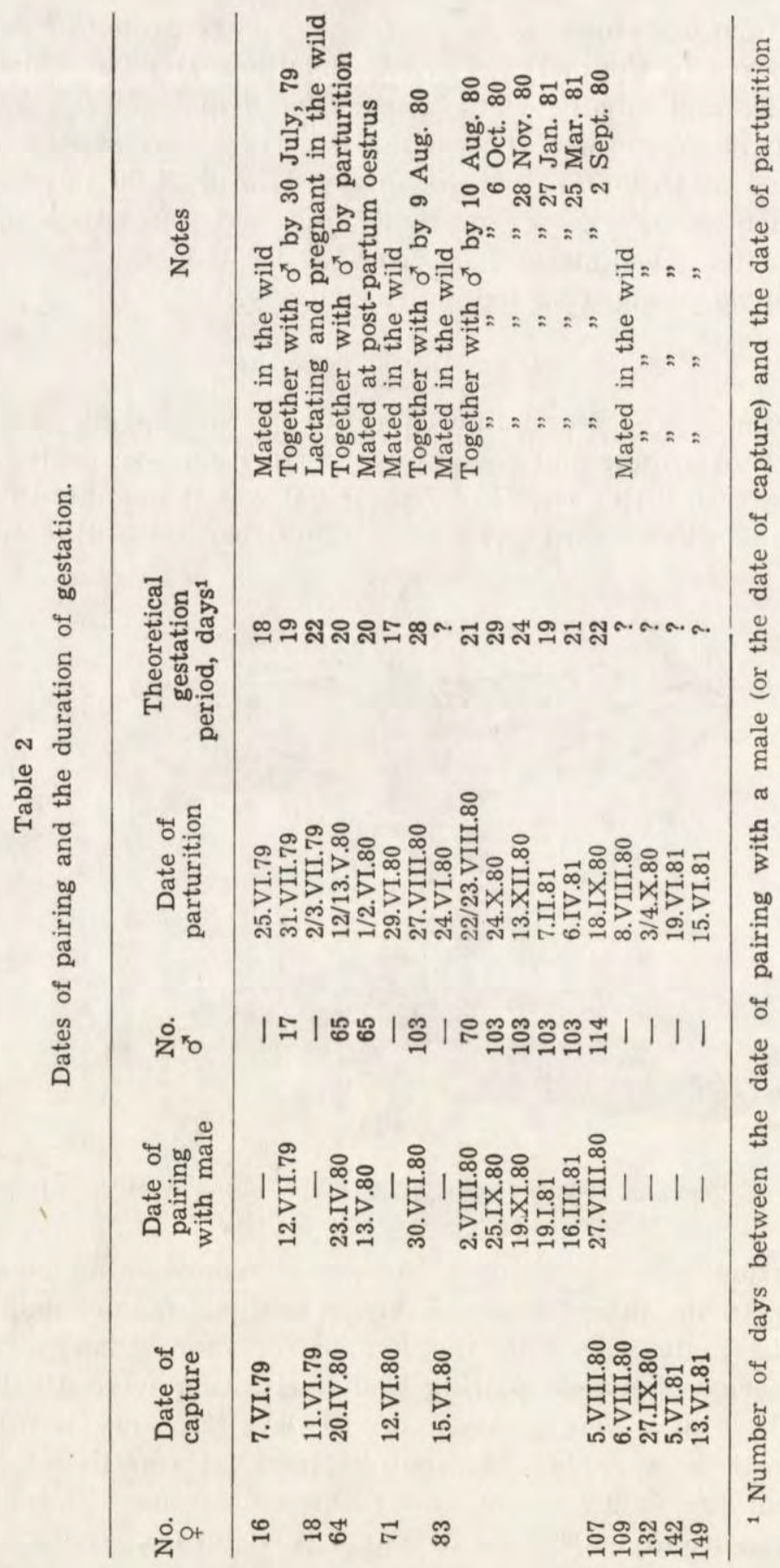


who was caught with clear sings of lactation. She mated in the field and delivered a litter after 22 days of captivity. Already Price (1953) and Vogel $(1970,1972)$ have noticed that pregnancy covers more time in lactating females, since the embryonic development of some shrews, including the water shrew, is shorter than their development in the nest. In females mating at the post-partum oestrus, the implantation of the embryos of the successive litter is probably delayed (Vogel, 1981). As it has already been noted, only female 64 mated at the post-partum oestrus. But the earlier litter of this female was killed by the male shortly after parturition so that the female was not lactating when pregnant. The gestation period of this female was not prolonged since the sucking stimulus did not start its action.

\subsection{Time of Parturition}

To determine the time of the day when water shrews give birth most frequently, the nests of the females in last days of pregnancy were checked every few hours.

In 11 cases out of 18 , the time of parturition was determined to the nearest hour or $4-6$ hours. These litters were born during the day. In the other cases, the parturition occurred late in the evening, at night, or early in the morning, and it was accepted that it took place on the turn of the day in the morning of which the litter was found and the preceding day (Table 3 ).

The data collected show that the water shrews deliver litters at any time during the night and day.

\subsection{Litter Size and Fecundity of Females}

A total of 113 young of 18 litters were born. Litter size ranged from 3 to 15 (Tables 4 and 5). The average number of young per litter ( $\pm \mathrm{SD}$ ) was $6.27 \pm 2.78$, or $5.76 \pm 1.47$ if one litter of 15 is excluded. Relevant literature data are compared in Table 6.

The litter of 15 is the largest litter so far reported but only 8 of these young were weaned.

The number of litters per female generally varied from 1 to 2 (Table 4). An unusual number of 6 litters was born by female 83, caught on June 15,1980 . She was classified as a young of the year. She was pregnant when captured. Her first litter was born on June 24, 1980. Assuming that the breeding season in the Białowieża Forest begins in April (Dehnel, 1950; Borowski \& Dehnel, 1953), this female had to matured at the age of $5-6$ weeks. Such early maturity, soon after leaving the nest, is recorded for both $N$. fodiens and $S$. araneus (Bazan, 1955 ; Pucek, 1960). The sixth litter of female 83 was born on April 6, 1981. 
Table 3

Approximate distribution of parturitions by hour of the day.



1 This means that the parturition occurred between 10.00 p.m. and 8-9 a.m.

Table 4

Litter size and mortality rate.

\begin{tabular}{|c|c|c|c|c|c|}
\hline $\begin{array}{c}\text { No. } \\
\text { @ }\end{array}$ & $\begin{array}{l}\text { No. } \\
\text { litter }\end{array}$ & $\begin{array}{l}\text { No. of } \\
\text { young in } \\
\text { a litter }\end{array}$ & $\begin{array}{l}\text { No. of } \\
\text { young } \\
\text { weaned }\end{array}$ & $\begin{array}{l}\text { No. of. } \\
\text { young } \\
\text { died }\end{array}$ & $\begin{array}{c}\text { Days after birth } \\
\text { when mortality } \\
\text { occurred }\end{array}$ \\
\hline \multirow[t]{2}{*}{16} & I & 6 & 0 & 6 & $7 / 8$ \\
\hline & II & 3 & 1 & 2 & $9 \& 13$ \\
\hline 18 & I & 6 & 6 & 0 & - \\
\hline \multirow[t]{2}{*}{64} & I & 8 & 0 & 8 & 1 \\
\hline & II & 6 & 6 & 0 & - \\
\hline \multirow[t]{2}{*}{71} & I & 15 & 8 & 7 & $1-7$ \\
\hline & II & 4 & 4 & 0 & - \\
\hline \multirow[t]{6}{*}{83} & I & 5 & 3 & 2 & $3 \& 5$ \\
\hline & II & 4 & 4 & 0 & - \\
\hline & III & 6 & 6 & 0 & - \\
\hline & IV & 6 & 6 & 0 & - \\
\hline & V & 7 & 7 & 0 & - \\
\hline & VI & 4 & 4 & 0 & - \\
\hline 107 & I & 5 & 0 & 5 & $1,3 \& 5$ \\
\hline 109 & I & 8 & 8 & 0 & - \\
\hline 132 & I & 6 & 6 & 0 & - \\
\hline 142 & I & 7 & 7 & 0 & - \\
\hline 149 & I & 7 & 7 & 0 & - \\
\hline
\end{tabular}

Table 5

Fertility of captive females.

\begin{tabular}{lcccccccccc}
\hline No. of youngs in a litter & 3 & 4 & 5 & 6 & 7 & 8 & $\ldots$ & 15 & Total & Avg. \pm S.D \\
\hline Frequency of litters & 1 & 3 & 2 & 6 & 3 & 2 & & 1 & 18 & $5.76 \pm 1.43^{1}$ \\
\hline
\end{tabular}

1 Mean calculated excluding the litter of 15 
She was rearing the young by May, 15, 1981 until lactation was stopped, and on May 17, 1981 she was separated from her litter. This female was, therefore, either lactating or pregnant for 346 days (June 4, $1980-$ May 15, 1981), with short intervals. Two farther attempts at mating failed, and the female died on July 12,1981 . Such a long reproductive period of this female provides evidence for the reproductive capacity of this species in captivity.

\subsection{Causes of Litter Mortality}

Thirty of $113(26.5 \%)$ water shrews born in captivity died. Generally lack of maternal care was not the reason for these losses. In most cases the young died in the first days of life (Table 4).

Three out of 18 litters born in captivity were totally lost. Part of three other litters survived. Only one litter died because of the lack of maternal care (female 107) (no nest and apparently no lactation).

Table 6

Literature data on fertility in Neomys fodiens.

\begin{tabular}{lccl}
\multicolumn{1}{c}{ Region } & $\begin{array}{c}\text { Number of young } \\
\text { in a litter } \\
\text { Min.-Max. }\end{array}$ & \multicolumn{1}{c}{ Avg. } & Reference \\
\hline South England & $3-8$ & 6.8 & Price (1953) \\
Switzerland (lab. breeding) & $2-10$ & 6.1 & Vogel (1972) \\
Białowieża Forest & $3-9$ & 5.4 & Dehnel \& Borowski (1953) \\
Białowieża Forest (lab. breeding) & $3-15$ & 5.76 & Michalak (this paper) \\
Karelian SSR & $2-8$ & 5.8 & Ivanter et al. (1974) \\
Tartarian SSR & $4-10$ & 7.7 & Popov (1960) \\
West Siberia & $4-14$ & 6.8 & Stroganov (1957) \\
\hline
\end{tabular}

Two litters (females $64 \mathrm{I}$ and $16 \mathrm{I}$ ) were born in the presence of males. Both litters were killed and circumstantial evidence suggests that the males killed the young (Table 4). In all the other cases, the males were removed from cages as soon as an effective mating was recorded.

Female 71 gave birth to 15 young in the first litter recorded for her. The nest was checked immediately after parturition, when the young were wet and stuck together. Two of them were already dead. On day 2 there were 13 young in the nest. On day 7, 9 young in good condition were present. Unfortunately, one was casually killed at weighing. The remaining 8 young were weaned.

Female 83 delivered 5 young in the first litter, and 3 were weaned. This litter was examined in detail. Every day the young were removed from the nest, weighed, and photographed. On the second day of life two young were marked with black spots by means of a flomaster. One of them died on the third day and another one on the fifth day of life. This could have been a result of too long (about 10 minutes) a stay out of the nest during examination, accounting 
for an excessive cooling of the body, and/or a harmful effect of chemicals in the dye. This female reared 5 other whole litters, which were not disturbed during first days of life, nor marked.

Female 16 delivered 3 young in the second litter. Two died on days 9 and 13 for unknown reasons but the other shrew was weaned.

\subsection{Maternal Behaviour}

\subsubsection{Behaviour Prior to Parturition}

Females built characteristically nests only $2-3$ days prior to delivery. Moss was compacted in the outer part of the nest. The inner part was made of pieces of dry leaves enclosing a spheroid chamber. The entrance into the pot was tightly closed. The female entered the nest from the side adjacent to the cage wall, burrowing into the ground under the pot.

One day prior and 1-2 days after parturition the females did not eat meat, but they drank much milk.

\subsubsection{Behaviour with Nestlings}

After parturition, the female closed the entrance with moss each time she went in or out. A few days later, when the young became more mobile, the inner nest chamber was destroyed, only a cup lined with dry leaves being left.

During the first week after delivery, mother shrew spent most time in the nest, leaving it only for meals and to visit the latrine. Before going into the pot she waited a while at the entrance, then ran in quickly. In the second week she visited the second cage more and more frequently, and stayed in the pot there.

Throughout the period of rearing young, the female was very aggressive. She sqeaked each time the pot was moved, and if this did not frightened the "intruder", she jumped out of the pot and attacked the hands. She did not flee even when the nest was disturbed and the young were taken out. She squeaked and seized the human fingers. The female attempted to forcibly re-enter her cage when excluded.

The nest was orderly all the time. The female presumably consumed the feces of the young since none were found in it. From time to time she repaired the nest, with newly-acquired moss and dry leaves.

4.6.3. Behaviour towards Young that Left the Nest and Duration of Lactation

Young left the nest for the first time at the age of $23-25$ days. At that time the mother was still largely interested in them. On several occasions females with difficulty drove 23-24-day-old young to the nest often by the scruff and stuffed the pot from outside. Youngs ran away and squeaked when they were seized by the scruffs. Sometimes 
the female entered the pot and suddenly seized passing young by the scruff, pulling it under her body into the pot. Sometimes the female followed the young, biting them at the base of the tail, and driving them towards the nest, or she seized them by the scruffs and, walking backwards, pulled them into the nest.

Young 24-days or older remained in one nest, though more nest-boxes were available. Nursing generally occurred in the nest. Many times the young of this age were sucking their mothers outside the nest, usually in a corner of the cage (Plate II, Photos 3 and 5).

To determine the duration of the lactation period, the moment of suckling was observed. In addition, the nipples were examined. Nursing females had their nipples clearly elongated, the fur on the belly was stuck together, and the skin around them was often naked. The young were isolated from their mother most frequently before the end of lactation, at the age of about $30-35$ days. For three litters the time of lactation

Table 7

Results of separation females from their young.

\begin{tabular}{ccccc}
\hline $\begin{array}{c}\text { No. } \\
\text { 9 }\end{array}$ & $\begin{array}{c}\text { Time of } \\
\text { separations, } \\
\text { hrs }\end{array}$ & $\begin{array}{c}\text { Age of young } \\
\text { after rejoining, } \\
\text { days }\end{array}$ & $\begin{array}{c}\text { Time the young } \\
\text { spend with } \\
\text { females, }{ }^{1} \text { min }\end{array}$ & $\begin{array}{c}\text { Body weight } \\
\text { loss by } \\
\text { the female, g }\end{array}$ \\
\hline $83^{2}$ & 9 & 30 & 15 & 2.1 \\
83 & 14 & 33 & 30 & 2.8 \\
83 & 24 & 34 & 30 & 1.0 \\
$149^{3}$ & 60 & 32 & 3 & 1.4 \\
$149^{3}$ & 60 & 28 & 30 & 1.7 \\
$142^{3}$ & 60 & 32 & 30 & \\
\hline
\end{tabular}

1 The time spent together with young after rejoining.

2 The family rejoined in a cage containing only sawdust on the floor. The female gathered sawdust as if trying to build the nest.

${ }^{3}$ Litters of females (149 and 142) were exchanged each other (see page 18).

is exactly known because they were isolated after the end of lactation, i. e. after 38,39 , and 40 days respectively. After the end of lactation, the female run away from the young pushing their snouts under her belly. Naked skin around the nipples rapidly became covered with new fur. The behaviour of two females was observed towards their young after different periods of separation from the young. Results are summarised in Table 7 . In all cases young shrews were accepted by females and nursed. No aggressive behaviour towards young was observed even after $60 \mathrm{hrs}$ of separation (see section 5 ).

These observations suggest that the female can identify the young after a long period of separation, thus that the tight bonds between the young and the female are maintained when the litter left the nest. Lactation in females was not stopped, which may suggest that the feeding of the litter more than 30 days is not an effect of compulsory 
permanent contacts between the female and the young. The prolongation of the lactation period does not seem to be due to the stimulation of the nipples by sucking. Rather, it appears an effect of a long, physiologically conditioned lactation period.

First signs of aggressive behaviour within a family, such as chasing from food bowls, warning squeaking during encounters, not allowing others to enter the pot occupied by another shrew, appeared as late as about 50 days of life.

4.6.4. Behaviour towards Males

Observations of behaviour of lactating female in the presence of a male were made in two ways :

(1) The males were left in the cages of the pregnant females until parturition and a few days after it. One female was with the male from the mating period (female 64 ) and in the second case the strange male was kept with the pregnant female for 14 days before the parturition (female 16). During the period of nest building and just after the parturition females were very aggressive towards males. Fights were observed frequently (see page 11).

(2) The males were put into the cages of the lacting females for a few hours. A male was put into the cage of the female 109 on days 2 and 3 of rearing the litter. Each time the female immediately attacked him. The male did not attack the female first and beeing attacked run away.

Aggressive behaviour towards the male was persisted even when the young had left the nest. A male was put for a few hours into the cage of female 83 when the young were 25 and again when they were 27 days old. The female chased him to the other cage, and closed with moss the connective tube. She subsequently removed the moss and attacked him again. The aggression of the female was not only the response to a strange male who appeared in her cages, but it was also related to the defence of the young. The evidence for this is provided by another example. The same female was moved together with a male to two new cages when the young were 32 days old. The female was aggressive at the beginning, but after an hour she stopped attacking the male, hid herself in one of the pots, and squeaked at the male when he approached her. Three hours later two young were placed in these cages. The female was retrived and suckled them. When the young entered the pot, she was running from the pot with the young to the male and back; and persistently attacked the male. The male, who was interested in her as long as she was alone, did not leave his pot when the young were present, and sought other shelter when the female chased him from it. When the male was removed, the female became quiet. 


\subsection{Age of Independence}

To determine the age at which the young gain "compulsory independence", it is enough to know when they start eating meat sufficient for survival without mother's milk. In captivity the young drank milk from bowls for the first time on day 24, and meat on day 27. And just on day 27 the incisors of young water shrews become sharp-pointed.

Young were separated from the mother after 30 days of life. Only one litter was separated earlier, at the age of 28 days, since the female appeared to be in poor condition. The young of this litter began to drink milk two days earlier, and on the day of separation they started eating meat. No evidence was found for the deterioration of their growth as a result of forced weaning.

These data suggest that young reach compulsary independence at 27-28 days of age. Vogel (1972) also found that the young water shrews become independent at the age of 28 days. It should be emphasized, however, that this conclusion is based on laboratory observations, where food is easily available in excess, and there is no need to search for food as would be neccessary in the wild.

It is much more difficult to determine the age at which shrew become "optionally independent". Such features will be considered here as the period of lactation in females, interest of the female in the young after leaving the nest, and the first display of aggression between the mother and the young. Data presented above (section 4.6 .3 and 4.6.4) show, that the time of lactation coincides with the period of interest in the young. After day 30 , the female spends less and less time with the young, though she is in contact with them at least when nursing. At the end of lactation period the female clearly avoids the young, but only after the termination of lactation she runs away from them (on days 38-40). It seems, therefore, that the end of lactation determines the date of "optional independence". Since that time the contacts between the young and their mother do not result from an actual need for contacts, but they are casual encounters due to sharing the same cages. The fact that approximately by day 50 no aggressive behaviour is displayed between the young and their mother can be explained by a mutual tolerance, and most probably by the tolerance of the female, independent of whether these are her own young or not (see section 6).

Additional information on the time of independence of the young were obtained by calculating time intervals between successive litters for females 83 and 71 , which delivered several litters (Table 2).

Female 83 was separated from her litters at different ages. After being separated from the first litter on day 39 and from the fourth litter on day 38 , she was paired and mated on the following day in the first case and on the same day 
in the second case (data on the date of mating were obtained assuming a 20-day gestation period and subtracting it from the time between the introduction of the male and the birth of the young). The same female, when separated from the litters on days 34 and 31 (the second and the third litters), mated after only 9 and 4 days respectively following the introduction of the male.

Female 71 was separated from the 28-day-old young. She was isolated for 4 days, then a male was introduced, and they mated 8 days afterwards.

These examples show that the females separated from the younger litter do not go into an oestrus condition immediately. Perhaps if copulation does not take place at the post-partum oestrus, the female can mate only after the termination of the physiologically determined lactation period, independent of whether or not she is nursing the young. Theoretically calculated time the female needs for rearing the young, i. e., the number of days from the parturition to the next oestrus is $35-39$ days.

Similar calculations, based on data for pregnant and nursing shrews in the wild, were made by Price (1953), who found that the lactation period lasts 37 days; the time interval between successive litters is 61 days (based on the assumption that the gestation period is 24 days).

In this study the time interval between successive litters was $57-61$ days (assuming a gestation period of 19-21 days and a lactation period of 38-40 days). Thus the results obtained by Price (1953) are almost totally consistent with the present results, except for the gestation period. This consistency between the field and laboratory results confirms the conclusion that the young are together with their mother for about 40 days and, therefore, only at this age they become "optionally independent".

\section{SOCIAL BEHAVIOUR}

This section analyses the behaviour of water shrews in a "family" group made up of a female with the young before it breaks up and also afterwards. To compare the behaviour patterns in related and unrelated animals, some observations were also made on the behaviour of previously separated animals subsequently forced to live in the same cage.

Social bonds in water shrews persisted to the age of 50 days. During this time contact-behaviour was observed between the family members. This behaviour is revealed first in the common utilization of the nest. Young shrews continued to occupy the natal nest for about 30 days, although other nestboxes were available. Then they moved to different nestboxes singly or in groups. Only at the age of about two months did they occupy the pots singly. 
Though individual juveniles had no sharply delimited territories in the cage, they displayed aggressive behaviour towards siblings attempting to enter occupied pots. Usually a "warning squeak" uttered by the occupant was sufficient to drive off the approaching animal. Young showed also close contact-behaviour when they were moved to a new cage without nestbox. At first they run along the walls of the cage but after few minutes they huddled together in a corner of the cage. They climbed up one another and motionless clung to one another for a few minutes, then they changed their positions and again became motionless. If mother was with them, young crawled under her belly and finally the female was on the top of young. The female sniffed and observed the area of the cage (Plate II, Phots 1, 2, 4). Sometimes young pushed only their snouts under mother's belly and also lay quietly.

Another indication of "familial" behaviour of water shrews, or at least for mutual tolerance among young siblings, was manifested in their feeding behaviour. Young siblings did not chase one another and did not react to their close proximity at the feeding bowls (Plate I, Photo 2). Adults, whether related or not, were never seen eating together. Shrews older than 60 days kept together in connected cages, did not fight, but clearly avoided encounters, most frequently stopping, sniffing at a distance, and running in diverging directions. Sometimes encounters lasted longer, particularly when one animal approached the food bowl at which another individual was already present. Then each emitted threatening squeaks, and reared up on the hind legs. After a sniffing period one of them retreated. Encounters between strange, unrelated shrews frequently ended in fight.

A hierarchy was established within sibling groups. There were no cases of biting to death, and fights resulting in injury were not observed, though subserviant animals were chased from food bowls or from nestboxes by stronger siblings. It appeared that two females sharing 2 cages showed more aggressive attitude towards one another than two males in the same situation. When a male and a female shared cages, usually female predominated, and only when the female was much smaller than the male did she yield behaviourally.

Siblings were able to identify one another. To have evidence for this, a litter was put into an empty cage and a strange, young shrew was added. At first siblings readily attacked stranger, then they huddled together and stopped attacking it (if it did not approach).

It remains to be learned how siblings and their mother can identify one another. Dehnel (1950) stressed that they have a well developed sense of touch, the other senses being poorly developed. Laboratory observations reveal however that the sense of smell is important in 2 Acta Theriologica 
the water shrew. Females guarding the nest sniffed intensively, and the shrews sniffed each other during encounters. The alertness of the female increased if a male was introduced into the cage with the young even for a short time. For some time after the removal of the male, the female sniffed as if seeking the intruder. She also sniffed the young upon each encounter, but did not do this when she was alone with the young. Sibkov (1979), who tested the role of different senses in spatial orientation of water shrews and in common shrews, concluded that scent plays a dominant role in distinguishing obstacles at a distance.

In addition, water shrews can communicate with one another uttering different sounds. Nursing females during the period when the young were in the nest and also a few days later often emitted soft, almost indiscernible, squeaks before entering the pot, as if they wanted to signal their presence. They uttered different squeaks when driving the young into the nest; when defending her young being removed from the nest, or while chasing the male approaching the nest - staccato squeaks. Soft "alluring" calls were emitted by males and females during mating. Loud "protest" calls were uttered by the young held in the hands when they were more than 10 days old. Hutterer $(1976,1978)$ and Movčan \& Sibkov (1982) distinguished and described the possible behavioural function of some calls uttered by Neomys fodiens.

The next question was whether or not the lack of aggressive attitude of the female was limited only to her litter. An experiment was carried out in which the young born by female 149 were separated from their mother at the age of 30 days and rejoined her $60 \mathrm{hrs}$ later. These 32day-old young immediately started searching for the mother's nipples. When the female did not show aggressive behaviour towards her young, they were separated again. The 28-day-old young of female 142, were removed, and the litters of these two females were exchanged. Female 149 , though not feeding for more than 60 hours, entered the nest together with the strange young a few minutes later. When the pot was investigated, the young were attached to the strange female's nipples. At the same time, the 32-day-old young of female 149 were persistently tracking female 142, who finally fed them.

It could be suggested that a mutual tolerance is sufficient for shrews to form family groups perhaps also in the wild. Sometimes young shrews caught on the same day and placed together in one cage did not escape from one another, but behaved like the siblings reared in captivity. 


\section{DISCUSSION - SOCIAL BEHAVIOUR IN SORICIDAE}

To answer the question of whether Soricidae are social or solitary creatures, the literature data were reviewed on the behaviour of shrews in groups of both related and unrelated individuals. Also the author's data on the common shrew, Sorex araneus, were used (Michalak, unpubl.).

The first notice on the behaviour of female common shrews towards the young after weaning was made by Dehnel (1952). He recommends separating the 22-23-day-old young from the female because after learing a nest there is much aggression between them. He remarked that the female cannot recognize the young if they are separated for about 5-6 hours. This suggests, that the common shrew is a solitary animal even soon after weaning. Crowcroft (1963) suggests, however, that the time of breaking up the family in the common shrew depends on the state of food supply and whether or not the female is pregnant again. In addition, he reports hunting in packs, which indicates that solitary habits in the common shrew are not always developing soon after weaning. The results of author's observations on the behaviour of female common shrews and their young support Crowcroft's (1963) findings. Four litters of common shrew observed in captivity left the nests on day 21, and on the same day they drank milk from bowls. They ate meat by 22 days. However, the female allowed them to nurse until day 28 . Thereafter the females clearly avoided the young, and the first, though weak, signs of aggression were displayed; the young uttered squeaks during encounters, and chased one another from food bowls. Thus the animals showed tolerance only for about one week after leaving a nest. They frequently shared a nest when resting. At 50 days a few shrews shared the same pot, but not a nest. At that time they were building nest sites at different levels, each of them with a separate entrance so that there was no direct contacts between them when they shared a nestbox. At this age common shrews displayed much aggression towards one another. Though fights were rare, keeping them afterwards in common cages resulted in death of some shrews.

Rudd (1953), who reared in captivity three other species of shrews (Sorex vagrans, Sorex ornatus, and Sorex sinuosus), did not record agonistic behaviour in immature non-sibling shrews, and immature siblings were very tolerant of one another, e.g., at the age of about two months they shared a nest when sleeping.

Hutterer (1978) described some behavioural aspects of Sorex minutus, and showed that close family bonds between the young and the female in this species are maintained for the first few months. He described 
the patterns of contact-behaviour indentical to these for the water shrews, namely, mounting one another and motionless clinging to one another, and also creeping of one shrew under another one. Such behaviour was maintained in the pygmy shrew to the age of $2-3$ months. During that time the female was able to recognize her young even after a two-day period of separation.

Observations on the behaviour of Neomys anomalus provide evidence that the female protects the young to the age of 30 days, and that strange animals of this species get used to one another rapidly, so that after several days of sharing a cage they may occupy the same nest (Michalak, 1982).

Conaway (1953) described Cryptotis parva as undoubtedly social animals. He described the process of rearing three litters born to females sharing a cage with several strange adults of both sexes. These strangers helped the mother to rear the young, e.g., when the nest with the young was damaged, they took part in the restoration of the nest, and were carried the young into it. In addition, adults were resting in a common nest, and gathered food in it. They also shared a latrine. Therefore, they formed a kind of a community, with no display of aggressive behaviour. Earlier Davis \& Joeris (1945) described a winter nest of this species, in which there were as many as 12 adult animals. Similarly, Hunt (1951) and Broadbooks (1952) found a nest of Cryptotis parva inhabited by a male, a female, and the young.

Vlasák (1972) has stated that young Crocidura suaveolens remain with the female after weaning, and they do not display any reluctance in mutual relationships. Also Goulden \& Meester (1978) have noticed lack of aggression between strange Crocidura marquensis kept in common cages, sharing food and a nest to sleep.

This review shows that Soricidae cover a large range of social behaviour patterns, but the data available do not allow generalization. Cryptotis parva offers the strongest evidence of being a social species. For Neomys fodiens and Sorex minutus the sings of social tolerance are much weaker. Nevertheless, the well developed contact-behaviour shows that also these species have very close family bonds, which however apparently persist for only a few weeks after leaving a nest.

Acknowledgements : Most of all I wish to thank Professor Zdzisław Pucek for careful reading of the paper, discussion, and editoral comments. Grateful acknowledgement is extended to Dr. Stanislaw Fedyk for critical comments on the first version of the manuscript, to Irena Szpakowicz, Walentyna Bajko, Jadwiga Kudlewska for their care for captive animals, and to Stefan Buszko, Jerzy Siemieniuk, and Witalis Szpakowicz for trapping the animals. Special thanks are also due to Dr. Gilbert L. Dryden (Slippery Rock State College) for his valuable comments and linguistic corrections. 


\section{REFERENCES}

1. Bazan I., 1955 : Untersuchungen über die Veränderlichkeit des Geschlechtsapparates und des Thymus der Wasserspitzmaus (Neomys fodiens fodiens Schreb.). Annls Univ. M. Curie-Skłodowska, C, 9 (1954), 5: 213-259.

2. Borowski S. \& Dehnel A., 1953: Materialy do biologii Soricidae. Annls Univ. M. Curie-Skłodowska, C, 7 (1952), $6: 305-448$.

3. Broadbooks H. E., 1952: Nest and behavior of a short-tailed shrew, Cryptotis parva. J. Mammal., 33: 241-243.

4. Conaway C. H., 1958 : Maintenance, reproduction and growth of the least shrew in captivity. J. Mammal., $39: 507-512$.

5. Crowcroft P., 1951: Keeping British shrews in captivity. J. Mammal., 32 : $354-355$.

6. Crowcroft P., 1957a: The life of the shrew. Max Reinhardt: 1-166. London.

7. Crowcroft P., 1957b: Shrews. [In: "The UFAW handbook on the care and management of laboratory animals", A. N. Worden, W. Lane-Petter, eds]. UFAW : 461-462. London.

8. Crowcroft P., 1963: Shrews. Animals of Britain, 17: 1-28. Sunday Time Publ. London.

9. Davis W. B. \& Joeris L., 1945: Notes on the life - history of the little short-tailed shrew. J. Mammal., 26: 136-138.

10. Dehnel A., 1950: Badania nad rodzajem Neomys Kaup. Annls Univ. M. Curie-Skłodowska, C. 5, 1: 1-63.

11. Dehnel A., 1952: Biologia rozmnażania ryjówki S. araneus L. w warunkach laboratoryjnych. Annls Univ. M. Curie-Skłodowska, C, 6 (1951), 11: 359-376.

12. Dryden G. L., 1968: Growth and development of Suncus murinus in captivity on Guam. J. Mammal., 49: 51-62.

13. Dryden G. L., 1969: Reproduction in Suncus murinus. J. Reprod. Fert., 6: $377-396$.

14. Dryden G. L., 1975: Establishment and maintenance of shrew colonies. [In: "International Zoo Yearbook", N. Duplaix-Hall, ed.]. 15: 12-18. London.

15. Fons R., 1972: La musaraigne musette Crocidura russula (Hermann, 1780). Sci. Nat., Paris, 112 : 23-28.

16. Goulden E. A. \& Meester J., 1978: Notes on the behaviour of Crocidura and Myosorex (Mammalia: Soricidae) in captivity. Mammalia, 42: 197-207.

17. Hanzák J., 1966: Vývoj mládát bělozubky sědé, Crocidura suaveolens (Pallas) 1821. Lynx, $6: 67-74$.

18. Hasler .J. M., Hasler .J. F. \& Nalbandov A. V., 1977: Comparative breeding biology of musk shrews (Suncus murinus) from Guam and Madagascar. J. Mammal., $58: 285-290$

19. Hellwing S., 1973: Husbandry and breeding of white-toothed shrews in the Research Zoo of the Tel-Aviv University. [In: "International Zoo Yearbook", N. Duplaix-Hall, ed.]. 13: 127-134. London.

20. Hunt T., 1951: Breeding of Cryptotis parva in Texas. J. Mammal., 32: 115-116.

21. Hutterer R., 1976: Beobachtungen zur Geburt und Jugendentwicklung der Zwergspitzmaus, Sorex minutus L. (Soricidae - Insectivora). Z. Säugetierkunde, $41: 1-22$.

22. Hutterer R., 1977: Haltung und Lebensdauer von Spitzmäusen der Gattung Sorex (Mammalia, Insectivora). Z. angew. Zool., 64: 353-367.

23. Hutterer R., 1978: Paarungsrufe der Wasserspitzmaus (Neomys fodiens) und verwandte Laute weiterer Soricidae, Z. Säugetierkunde, $43: 330-336$. 
24. Ivanter T. V., Ivanter E. V. \& Ternouško E. J., 1974: Biologija razmnoženija i struktura populjacij zemleroek (Soricidae) Karelii. [In: "Voprosy ekologii životnych", E. V. Ivanter, ed.] : 95-143. Petrozavodsk.

25. Kilham L., 1951: Mother and young of Sorex cinereus fontenalis in captivity. J. Mammal., $32: 115$.

26. Lorenz L., 1957: The European water shrew (Neomys fodiens Pallisant, 1871). [In: "The UFAW handbook on the care and management of laboratory animals", A. N. Worden, W. Lane-Petter, eds.]. UFAW : 469-472. London.

27. Michalak I., 1982: Reproduction and behaviour of Mediterranean water shrew under laboratory conditions. Säugetierkdl. Mitt., 30:307-310.

28. Mock O. B. \& Conaway C. H., 1976 : Reproduction of the least shrew (Cryptotis parva) in captivity. [In: "The laboratory animal in the study of reproduction" 6th ICLA Symp. Thessaloniki 1975, Th. Antikatzides, S. Erichsen, A. Spiegel, eds]. G. Fischer Verlag : 59-71. Stuttgart, New York.

29. Movčan V.N. \& Sibkov A.A., 1982: Strukturnye osobennosti akustičeskich signalov zemleroek (Soricidae). Zool. Ž., 61: 1695-1705.

30. Pearson O.P., 1944: Reproduction in the shrew (Blarina brevicauda Say). Am. J. Anat., $75: 39-93$.

31. Pearson O.P., 1950: Keeping shrews in captivity. J. Mammal., 31: 351-352.

32. Popov V.A., 1960: Mlekopitajuščie Volžsko-kamskogo kraja. Nasekomojadnye, rukokrylye, gryzuny. Akad. Nauk SSSR, Kazanskij Filial: 141-145. Kazan'.

33. Price M., 1953: The reproductive cycle of the water shrew, Neomys fodiens bicolor. Shaw. Proc. zool. Soc. Lond., 123 : 599-621.

34. Pucek Z., 1960 : Sexual maturation and variability of the reproductive system in young shrew (Sorex L.) in the first calendar year of life. Acta theriol., $12: 269-296$.

35. Rood J., 1958: Habits of short-tailed shrew in captivity. J. Mammal., 39: 449-507.

36. Rudd R. L., 1953: Notes of maintenance of behaviour of shrews in captivity. J. Mammal., 34 : 118-120.

37. Schwentker V., 1957: The short-tailed shrew (Blarina brevicauda Say). [In: "The UFAW handbook on the care and management of laboratory animals", A. N. Worden, W. Lane-Petter, eds]. UFAW : 463-468. London.

38. Sibkov A. A., 1979: Rol sensornych sistem v bližnej orientacii zemleroek rodov Sorex i Neomys, Zool. Ž., 58: 76-81.

39. Vlasák P., 1972: The biology of reproduction and post-natal development of Crocidura suaveolens Pallas, 1811 under laboratory conditions. Acta Univ. Carol., Biol. 3 (1970) : 207-292.

40. Vogel P., 1970: Biologische Beobachtungen and Etruskerspitzmäusen (Suncus etruscus Savi, 1832). Z. Säugetierkunde, 35: 173-185.

41. Vogel P., 1972: Beitrag zur Fortpflanzungsbiologie der Gattungen Sorex, Neomys und Crocidura (Soricidae). Verh. naturf. Ges. Basel, 82: 165-192.

42. Vogel P., 1973: Vergleichende Untersuchung zum Ontogenesemodus einheimischer Soriciden (Crocidura russula, Sorex araneus und Neomys fodiens). Rev. suisse Zool., 79: 1201-1332.

43. Vogel P., 1981: Occurrence and interpretation of delayed implantation in insectivores. J. Reprod. Fert., $29: 51-60$.

Accepted, December 20, 1982. 
Iwona MICHALAK

ROZROD, BEHAWIOR MACIERZYŃSKI I SOCJALNY RZESORKA RZECZKA W WARUNKACH LABORATORYJNYCH

\section{Streszczenie}

Dysponowano materialem 18 miotów Neomys fodiens Pennant, 1771, (113 młodych) urodzonych od samic ciężarnych $\mathrm{z}$ terenu $(\mathrm{n}=8)$ i od samic zapłodnionych w hodowli $(\mathrm{n}=10)$ (Tabela 1). Podano opis przebiegu kopulacji (Ryc. 1), ustalono długość ciąży (19-21 dni) (Tabela 2), czas trwania laktacji (38-40 dni). Ilość młodych w miotach wynosiła od 3 do 15 (Tabela 5) przy średniej wynoszącej $5,76 \pm 1,43$ (bez miotu z 15 młodymi). Samice przeciętnie rodzily $1-2$ mioty, tylko od jednej samicy udało się otrzymać aż 6 miotów a w nich 32 młode (Tabela 4). Samica ta była przez 346 dni stale albo ciężarna albo karmiąca z małymi, kilkudniowymi przerwami. W hodowli urodził się najliczniejszy jak dotąd wiadomo z literatury miot liczący 15 młodych, z których tylko 8 odchowało się do uzyskania samodzielności.

Obserwacje behawioralne dotyczyły głównie zachowania się samicy w trakcie wychowywania młodych, w czasie ich rozwoju gniazdowego oraz zachowania się samicy w stosunku do miotu, który opuścił już gniazdo. Okazało się, że samica wykazuje duże zainteresowanie się młodymi do około 40 dnia ich życia. W tym czasie występuje behawior kontaktowy między członkami rodziny, który uwidacznia się między innymi we wspólnym użytkowaniu gniazda oraz przytulaniu się zwierząt do siebie w chwili, gdy czują się zagrożone np. po włożeniu ich do pustej, niewyposażonej klatki (Fot. 1, 2, 4). Samica zdolna jest rozpoznać młode po 2,5 dobie niekontaktowania się z nimi (Tabela 7).

Przeprowadzono dyskusję na temat występowania behawioru socjalnego w rodzinie Soricidae, przy czym Neomys fodiens, Sorex minutus oraz Cryptotis parva zaliczono do tych ryjówkowatych, u których przynajmniej przez pewien okres życia występuje wyraźna więź rodzinna. 


\section{EXPLANATION OF PLATES}

\section{Plate I}

Photo 1. The equipment of a cage. Arrow indicates metallic shutter closing hole in the wall of the cage.

Photo 2. 59-day-old young eating meat from a common food bowl.

\section{Plate II}

Photos 1, 2, and 4. 31-day-old litter transferred to a new cage without nestboxes. Photos 1 and 4. A female resting on the top.

Photo 2. A litter without mother.

Photo 3 and 5. Feeding of 24-day-old young in a corner of the cage.

Photo 3. immediately prior to nursing; first young approaching posturing female. Photo 5. female moving away from young after feeding them. 
ACTA THERIOLOGICA, Vol. XXVIII, 1.

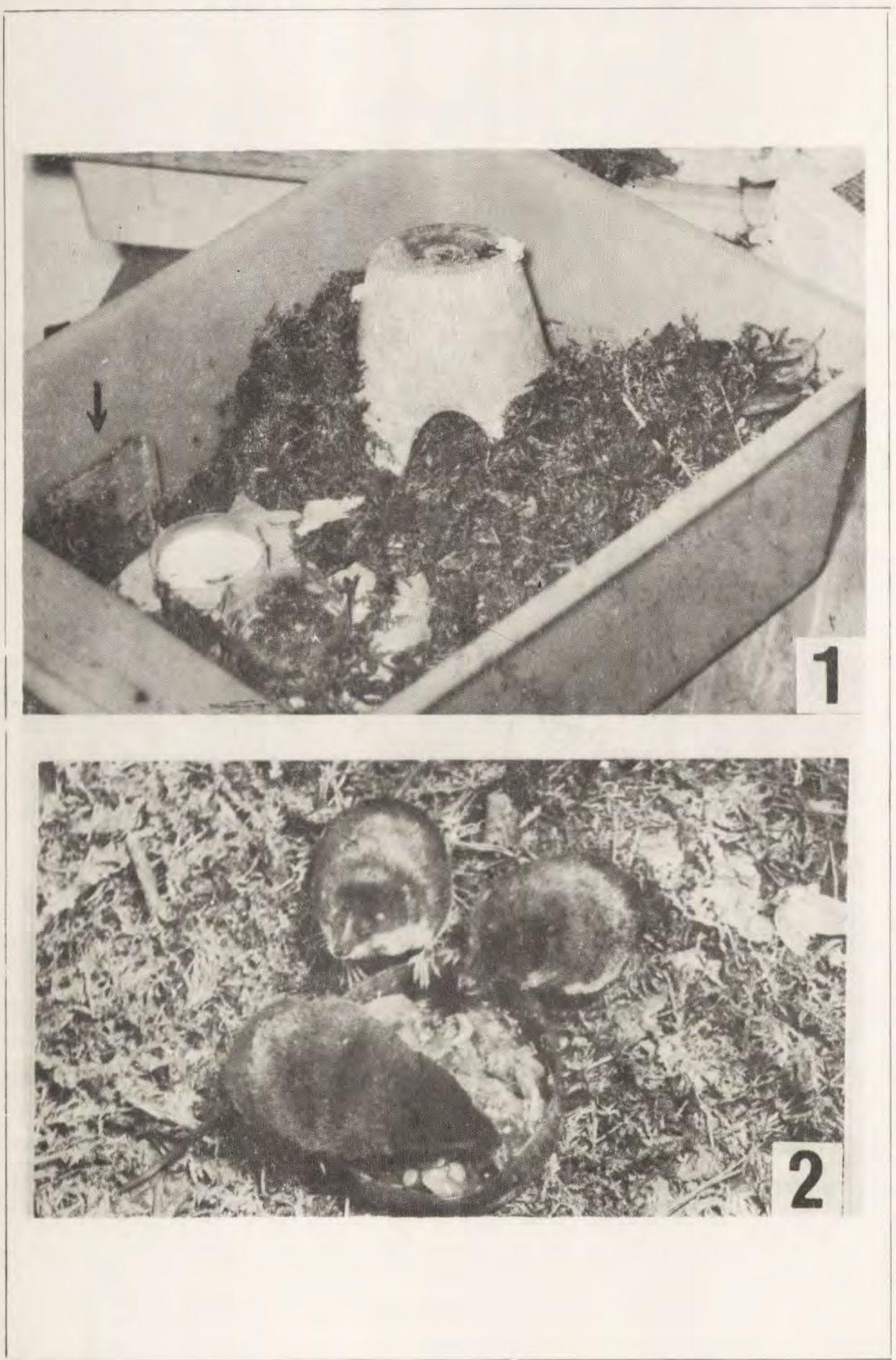

I. Michalak

S. Buszko phot. 
ACTA THERIOLOGICA, Vol. XXVIII, 1.

Plate II.

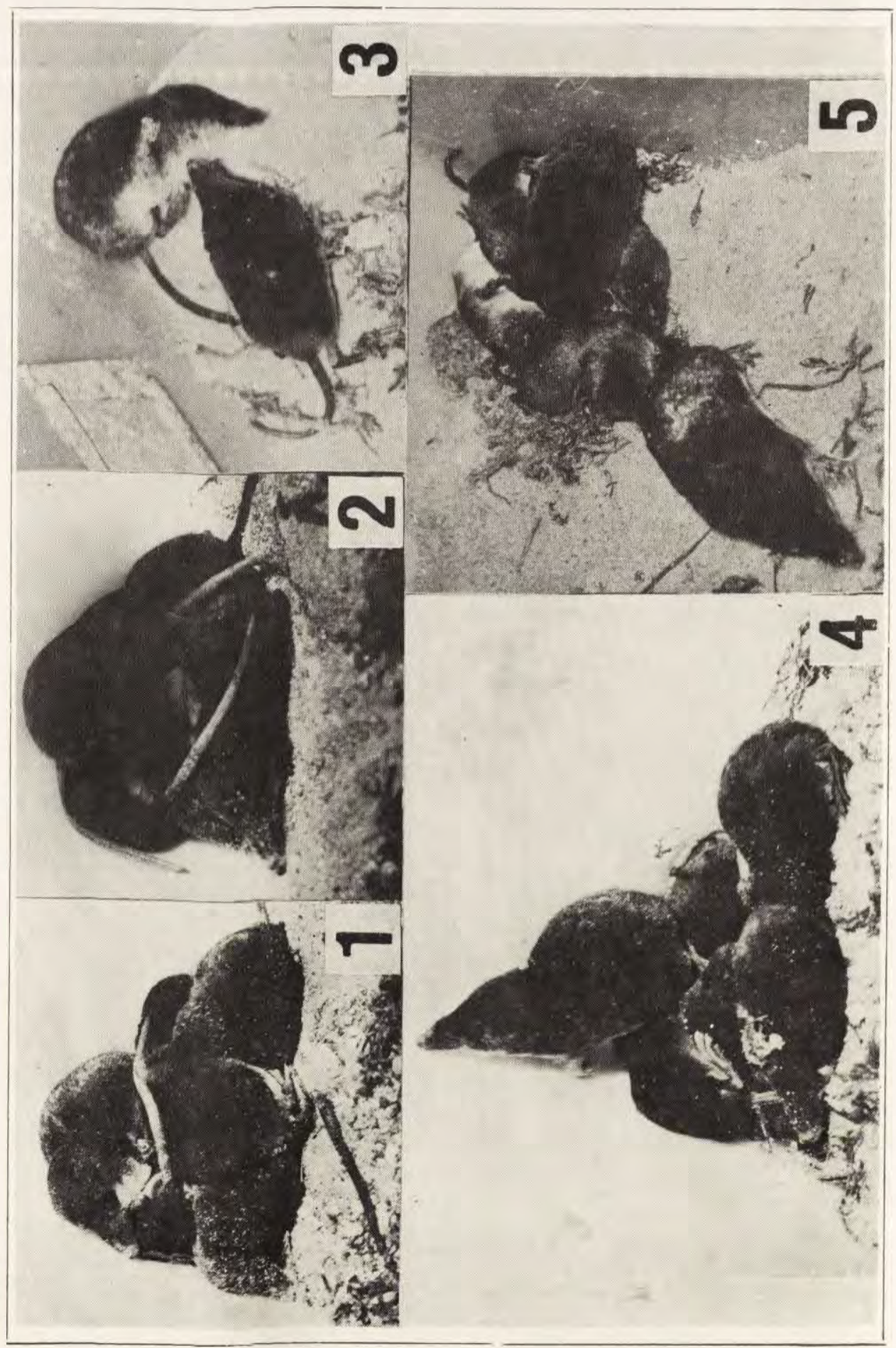

I. Michalak

S. Buszko phot. 